\title{
Kudoa saudiensis sp. n. (Myxosporea: Multivalvulida) infecting oocytes of the Indian mackerel Rastrelliger kanagurta (Perciformes: Scombridae)
}

\author{
Lamjed Mansour $^{1,2}$, Abdel Halim Harrath ${ }^{1}$, Abdel-Azeem S. Abdel-Baki ${ }^{1,3}$, Saleh Alwasel ${ }^{1}$, Saleh Al-Quraishy ${ }^{1}$ \\ and Suliman Y. Al Omar ${ }^{1}$
}

\author{
${ }^{1}$ Zoology Department, College of Science, King Saud University, Riyadh, Saudi Arabia; \\ ${ }^{2}$ Unité de Recherche de Biologie Intégrative et Ecologie Évolutive et Fonctionnelle des Milieux Aquatiques, Département de \\ Biologie, Faculté des Sciences de Tunis, Université de Tunis El Manar, Tunisia; \\ ${ }^{3}$ Zoology Department, Faculty of Science, Beni-Suef University, Egypt
}

\begin{abstract}
During a survey the occurrence of Kudoa quraishii Mansour, Harrath, Abd-Elkader, Alwasel, Abdel-Baki et Al Omar, 2014, recently identified in the muscles of the Indian mackerel, Rastrelliger kanagurta (Cuvier), a species of Kudoa Meglitsch, 1947 infecting oocytes of mature females of the same host fish was found. The new species, for which the name Kudoa saudiensis sp. n. is proposed, infects oocytes that are enlarged with a whitish colour. The parasite develops in vesicular polysporous plasmodia within the oocyte. Infection occurs with a mean prevalence of $20 \%$ (7/35) of examined females. Mature spores are quadratic in shape in apical view, having four equal valves and four symmetrical polar capsules. Fresh spores are 2.4-3.6 $\mu \mathrm{m}$ long (mean \pm SD $3.1 \pm 0.3 \mu \mathrm{m}$ ), $4.3-5.4 \mu \mathrm{m}$ $(4.7 \pm 0.3 \mu \mathrm{m})$ wide and 3.4-4.3 $\mu \mathrm{m}(3.8 \pm 0.3 \mu \mathrm{m})$ in thickness and long. The smaller size of the new Kudoa species was the distinctive feature that separates it from all previously described species. Molecular analysis based on the SSU rDNA sequences shows that the highest percentage of similarity of $98.5 \%$ was observed with K. ovivora Swearer et Robertson, 1999, reported from oocytes of labroid fish from the Caribbean coasts of Panama. The percentage of similarity was $98 \%$ with K. azevedoi Mansour, Thabet, Chourabi, Harrath, Gtari, Al Omar et Ben Hassine, 2013 and 89\% with K. quraishii. Phylogenetic analysis of the SSU and LSU rDNA data revealed a consistent of the new species with $K$. azevedoi and $K$. ovivora. Our findings support the creation of Kudoa saudiensis sp. n. that infects oocytes of the Indian mackerel Rastrelliger kanagurta.
\end{abstract}

Keywords: Myxozoa, ultrastructure, phylogeny, Red Sea, Saudi Arabia

The Myxozoa is a large group of microscopic parasites widely distributed and commonly found infecting fish (Kent et al. 2001, Canning and Okamura 2004, Lom and Dyková 2006). Myxozoan infection is often associated with diseases that can cause considerable economic loss (Lom and Dyková 2006). Recently, increasing attention has been paid to myxosporean parasites belonging to the genus Kudoa Meglitsch, 1947 of the monotypic family Kudoidae Meglitsch, 1960 that are characterised by the production of myxospores having four or more shell valves and polar capsules (Egusa 1986, Kent et al. 1994, Canning and Okamura 2004, Lom and Dyková 2006). The number of nominal Kudoa species is 95, making them one of the largest genera of described myxosporeans (Eiras et al. 2014).

These parasites are typically histozoic, infecting mainly somatic musculature of marine and freshwater fish (Egusa 1986, Lundy et al. 1999, Burger et al. 2008). Some of species can cause economic loss through the induction of post-mortem myoliquefaction of fish muscles and by the production of unsightly macroscopic cysts in fish musculature (Lom and Dyková 2006). Infections due to Kudoa may also occur less frequently in other organs as a result of tissue tropism or as a consequence of systemic infection. Thus, infections have been reported in various organs such as gills, fins, intestine, heart, kidneys, brain and ovaries (Moran and Kent 1999, Mansour et al. 2013).

Characterisation of Kudoa parasites at the species level is sometimes ambiguous when it depends entirely on the shape and dimensions of the mature spore because of the paucity of its morphological features. Molecular characterisation has allowed more accurate identification, particularly when combined with morphometric data of the mature spore, infected tissue, host species and geography (Whipps et al. 2004, Adlard et al. 2005). Molecular characterisation, based particularly on the small subunit ribos- 
omal DNA (SSU rDNA) and the large subunit ribosomal DNA (LSU rDNA), has allowed the revision of some species previously considered as different on the basis of the infected hosts species and/or their different geographic distribution (Burger and Adlard 2010a, 2011, Heiniger et al. 2013).

Kudoa histolytica Pérard, 1928 infecting the Atlantic mackerel Scomber japonicus Houttuyn was discovered to be identical with $K$. thyrsites Gilchrist, 1924 after molecular analysis was performed (Levsen et al. 2008). Kudoa amamiensis Egusa et Nakajima, 1980 has been reported worldwide with differences in spore morphometry in more than 10 different host species, but its identification has been facilitated through numerous molecular studies (Egusa and Nakajima 1980, Whipps et al. 2003, Diamant et al. 2005, Burger et al. 2008, Burger and Adlard 2011).

In addition, different species of Kudoa with more than four shell valves have been reported having different morphotypes (morphology of spore and number of shell valves) but with identical SSU rDNA sequence (Burger and Adlard 2010b, Miller and Adlard 2012, Heiniger et al. 2013). Kudoa yasunagai Hsieh et Chen, 1984 infecting the brain of several fish species, such as Lateolabrax japonicus (Cuvier), Oplegnathus fasciatus (Temminck et Schlegel), Seriola quinqueradiata Temminck et Schlegel, Paralichthys olivaceus (Temminck et Schlegel) and Plotosus lineatus (Thunberg) in Japan, the Philippines and Australia, have been recorded with differences in the number of shell valves but with highly similar rDNA sequences (Burger et al. 2008, Burger and Adlard 2010b, Miller and Adlard 2012, Shirakashi et al. 2012, Ishimaru et al. 2014).

In the Saudi Arabian coasts, only one Kudoa species, K. quraishii Mansour, Harrath, Abd-Elkader, Alwasel, Abdel-Baki et Al Omar, 2014 has been reported infecting the skeletal muscle of the Indian mackerel, Rastrelliger kanagurta (Cuvier) in the Red Sea and Arabian Gulf (Mansour et al. 2014).

During an assessment of the occurrence of K. quraishii, we noticed the presence of whitish and large-sized oocytes in mature females of the Indian mackerel. When observed under the light microscope, the cytoplasm of the infected oocytes appears to be filled with spores of Kudoa. These spores were morphometrically different from those of $K$. quraishii. In this paper we present a description of this new species of Kudoa using structural, ultrastructural, histological and molecular data.

\section{MATERIALS AND METHODS}

Between June and September 2013, 58 Indian mackerel, Rastrelliger kanagurta (23 males and 35 females) were bought from fisherman in Jeddah. Fish were also sampled between September and November 2013 from Jazan (30 males and 42 females) and Dammam (45 males and 23 females). The total length varied between 12 and $26 \mathrm{~cm}$. After dissection, all organs were removed to a Petri dish and examined under stereomicroscope. Smears were made from each organ and examined under the light microscope at magnification of $400 \times$ to verify the presence of myxospores. Gonads were examined to identify sex of the fish. Infected ovaries were removed and washed with sterile PBS buffer.
Individual oocytes were carefully removed using a plastic pipette. For spore measurements and morphological analysis, oocytes were squashed onto a microscope slide beneath a coverslip to release spores, which were observed with a light microscope (Olympus BX 51) equipped with a digital camera (Olympus DP72). For phase contrast observations, micrographs of fresh prepared spores were taken at $600 \times$ magnification on a Zeiss LSM 700 microscope equipped with Nomarski Differential Interference Contrasting (DIC) optics. Measurements were taken from multiple images of fresh mounted preparations of spores following the recommendations of Lom and Arthur (1989). In addition, smear dried preparations were fixed in frozen methanol, stained with Giemsa and photographed.

To evaluate the effect of the parasite on the host cells, the diameters of infected $(n=50)$ and uninfected $(n=50)$ oocytes were measured under a stereomicroscope equipped with a reference micrometric rule and compared. Differences were estimated using a $t$-test.

For histological analysis, $0.5 \mathrm{~cm}^{3}$ of infected ovary was fixed in $10 \%$ formalin buffered solution, processed using standard histological protocol and stained with hematoxylin and eosin. Sections were photographed at different magnifications using a compound microscope.

For transmission electron microscopy, individual infected oocytes were fixed in $2.5 \%$ glutaraldehyde buffered with $0.1 \mathrm{M}$ sodium cacodylate $(\mathrm{pH} 7.3)$ at $4{ }^{\circ} \mathrm{C}$, washed with the same buffer and then postfixed with $1 \%$ osmium tetroxide in the same buffer for $1 \mathrm{~h}$. After washing three times in the cacodylate buffer, samples were dehydrated in increasing concentrations of ethanol and then embedded in Epoxy resin via propylene oxide. Sections were performed using a Leica Ultra-cut S ultramicrotome. Semi-thin sections were prepared and stained with $0.2 \%$ Azur Blue II, $\mathrm{pH}$ 8.5. Ultrathin sections were stained with uranyl acetate and lead citrate and examined with a Jeol Jem-1011 electron microscope.

For molecular analysis, infected oocytes were washed three times with PBS. Genomic DNA was extracted using a DNeasy ${ }^{\circledR}$ Blood \& Tissue Kit (Qiagen, Valencia, Califonia, USA) according to the manufacturer's instructions. For PCR amplification genomic DNA ( $100 \mathrm{ng})$ was added to $30 \mu \mathrm{l}$ of reaction mixture containing each, $200 \mathrm{mM}$ of each dNTP, $1.5 \mathrm{mM} \mathrm{MgCl}{ }_{2}, 1 \mathrm{xTaq}$ DNA polymerase buffer (MBI, Fermentas, St.Leon-Rot, Germany) and $1 \mathrm{U}$ of Taq DNA polymerase (MBI, Fermentas). Cycling conditions were as follows: one cycle of $94^{\circ} \mathrm{C}$ for $5 \mathrm{~min}$; $30 \mathrm{cy}$ cles of $94^{\circ} \mathrm{C}$ for $30 \mathrm{~s}, 52^{\circ} \mathrm{C}$ for $30 \mathrm{~s}$, and $72{ }^{\circ} \mathrm{C}$ for $2 \mathrm{~min}$; and one cycle of $72^{\circ} \mathrm{C}$ for $10 \mathrm{~min}$. The PCR product was then visualised under a UV-transilluminator after migration in $1 \%$ gel agarose electrophoresis. Size of the amplified fragment was estimated using a standard $1 \mathrm{kbp}$ DNA ladder marker (Solis, BioDyne, Tartu, Estonia).

The SSU rDNA partial sequence was amplified using the same primers used by Mansour et al. (2013); MyxF144 MyxF818, MyxF1338, MyxR862, MyxR1437, MyxR1944. These primers were used in different combinations of pairs, MyxF144MyxR862, MyxF818-MyxR1473, MyxF1338-MyxR1944 and MyxF818-MyxR1437, allowing amplification of four overlapping fragments. A fragment of the LSU rDNA gene was also amplified using the primers Kt28S1F and 28S1R (Whipps et al. 2004) with the following PCR conditions: initial denaturation at $94^{\circ} \mathrm{C}$ for $5 \mathrm{~min}$, followed by 30 cycles of $94^{\circ} \mathrm{C}$ for $30 \mathrm{~s}, 50^{\circ} \mathrm{C}$ for $30 \mathrm{~s}$, 
Table 1. Accession numbers of the SSU and LSU rDNA sequences of myxosporean species used for multiple alignment and phylogenetic tree construction. Percentages of similarities based on the Kimura-2 parameters were obtained after pairwise analysis of Kudoa saudiensis sp. n. and selected sequences.

\begin{tabular}{|c|c|c|c|c|}
\hline \multirow{2}{*}{$\begin{array}{l}\text { Myxosporean } \\
\text { species }\end{array}$} & \multirow{2}{*}{$\begin{array}{l}\text { SSU rDNA } \\
\text { accession } \\
\text { numbers }\end{array}$} & \multirow{2}{*}{$\begin{array}{l}\text { LSU rDNA } \\
\text { accession } \\
\text { number }\end{array}$} & \multicolumn{2}{|c|}{$\begin{array}{l}\text { Kimura-2 parameter } \\
\text { distance compared to } \\
\text { K. saudiensis }\end{array}$} \\
\hline & & & $\begin{array}{l}\text { SSU } \\
\text { rDNA }\end{array}$ & $\begin{array}{l}\text { LSU } \\
\text { rDNA }\end{array}$ \\
\hline Kudoa ovivora & AY152750 & AY302731 & 98.51 & 80.10 \\
\hline K. azevedoi & HQ540316 & - & 98.00 & - \\
\hline K. paraquadricornis & FJ792718 & FJ792752 & 97.70 & 79.28 \\
\hline K. scomberomori & AY302737 & - & 97.62 & - \\
\hline K. quadricornis & FJ792721 & FJ792754 & 97.62 & 79.83 \\
\hline K. grammatorcyni & AY302739 & AY302729 & 97.55 & 79.18 \\
\hline K. neothunni & AB693042 & AB710385 & 97.47 & 79.11 \\
\hline K. monodactyli & DQ439814 & FJ792748 & 97.24 & 76.70 \\
\hline K. permulticapsula & AY078429 & - & 97.16 & - \\
\hline K. septempunctata & AB553293 & AB693040 & 96.94 & 75.89 \\
\hline K. megacapsula & AB188529 & - & 96.94 & - \\
\hline K. lateolabracis & AY382606 & - & 96.94 & - \\
\hline K. ciliatae & DQ519390 & - & 96.79 & - \\
\hline K. whippsi & FJ792725 & JX090296 & 96.78 & 76.17 \\
\hline K. neurophila & AY17251 & GU808774 & 96.72 & 74.22 \\
\hline K. prunusi & AB573715 & - & 96.40 & - \\
\hline K. lethrini & DQ519388 & JQ026228 & 96.71 & 75.89 \\
\hline K. thalassomi & AY302738 & HM022136 & 96.71 & 77.79 \\
\hline K. minithyrsites & AY152749 & - & 96.63 & - \\
\hline K. yasunagai & AY302741 & JQ026229 & 96.48 & 76.38 \\
\hline K. thyrsites & AY941819 & GU191935 & 96.48 & 78.21 \\
\hline K. chaetodoni & JQ026218 & - & 96.41 & - \\
\hline K. inornata & FJ790311 & FJ790312 & 96.40 & 78.02 \\
\hline$K$. dianae & AF414692 & FJ417058 & 96.24 & 74.24 \\
\hline K. paniformis & AF034640 & AY302732 & 96.09 & 76.33 \\
\hline K. nova & EF644198 & - & 96.02 & - \\
\hline K. alliaria & DQ182561 & - & 95.70 & - \\
\hline K. rosenbuschi & AY623795 & - & 95.55 & - \\
\hline K. cookii & JX090294 & JX090303 & 95.40 & 76.38 \\
\hline K. iwatai & AB553295 & AB628193 & 95.16 & 67.86 \\
\hline K. hemiscylli & GU324957 & GU446629 & 95.00 & 70.56 \\
\hline K. carcharhini & GU324970 & GU446630 & 95.00 & 71.01 \\
\hline K. scomberi & AB693044 & AB693045 & 92.14 & 63.67 \\
\hline K. crumena & AF378347 & KC139230 & 91.90 & 62.12 \\
\hline K. shiomitsui & AY302724 & - & 91.81 & - \\
\hline K. leptacanthae & JQ974029 & JQ974030 & 91.73 & 64.71 \\
\hline K. thunni & AB553300 & AB553306 & 91.48 & 61.82 \\
\hline K. trachuri & AB553299 & AB553305 & 91.31 & 62.16 \\
\hline K. amamiensis & AY152748 & FJ792727 & 90.84 & 61.25 \\
\hline K. hypoepicardialis & AY302722 & - & 90.65 & - \\
\hline K. pagrusi & JF797621 & - & 90.60 & - \\
\hline K. kenti & FJ792713 & FJ792747 & 90.09 & 59.11 \\
\hline K. quraishii & KF413764 & KF830722 & 88.91 & 61.15 \\
\hline Ceratomyxa shasta & AF001579 & FJ981818 & 80.02 & 16.93 \\
\hline
\end{tabular}

and $72{ }^{\circ} \mathrm{C}$ for $1 \mathrm{~min}$ and a final extension of $72^{\circ} \mathrm{C}$ for $10 \mathrm{~min}$. Sequencing of generated fragments from three PCR products of the SSU rDNA and two LSU rDNA were carried out by Macrogen Inc. (Seoul, South Korea), using the same primers.

Generated overlapping sequences were assembled using the cap3 program (http://pbil.univ-lyon1.fr/cap3.php) and edited by visual inspection. The obtained $1557 \mathrm{bp}$ consensus sequences of the SSU rDNA and 803 bp of the LSU rDNA sequences were deposited in GenBank.

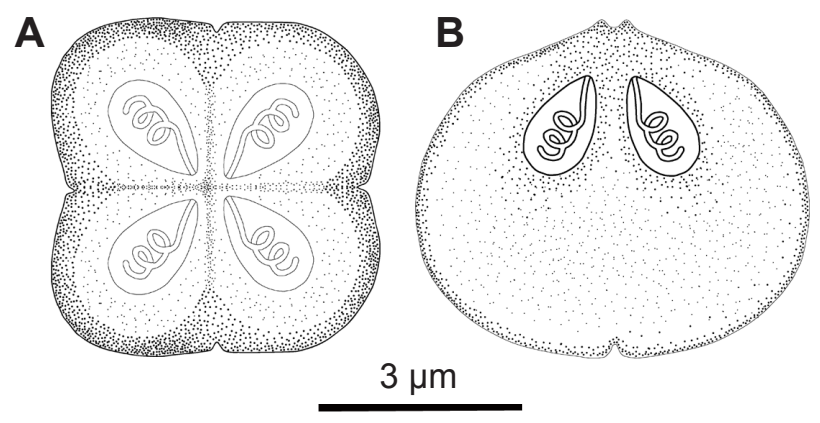

Fig. 1. Line drawing of the spore of Kudoa saudiensis sp. n. from Rastrelliger kanagurta in apical (A) and lateral (B) views.

SSU rDNA and LSU rDNA sequences of phylogenetically related species were extracted from GenBank, using the Basic Local Alignment Search Tool from the NCBI BLAST web portal (www.ncbi.nlm.nih.gov/BLAST). Forty eight SSU rDNA and thirty six LSU rDNA sequences were selected (Table 1). Sequences were aligned using the Clustal X version 2.0 (Larkin et al. 2007) with default parameters and then edited with the GenDoc software version 2.7 (http://www.nrbsc.org/gfx/genedoc).

Phylogenetic trees based on Maximum parsimony and Maximum likelihood methods were constructed with 1000 bootstrap replicates to assign confidence levels to branches using the MEGA software version 5 (Tamura et al. 2011). For that, 44 SSU rDNA sequences and 29 LSU sequences were used for the analysis. For all phylogenetic analyses Ceratomyxa shasta Noble, 1950 was used as outgroup. A pairwise distance matrix was performed with the Kimura-2 parameter model distance for transitions and transversions.

\section{RESULTS}

Kudoa saudiensis sp. $\mathrm{n}$.

Figs. 1-5

ZooBank number for species

urn:1sid:zoobank.org:act:1FFA2659-F353-4E2A-AA9A-

2E4DBC869A33

Spore morphology (based on 30 spores; measurements in micrometres).

Spores stellate in shape with 4 equal symmetrical valves and rounded peripheral edges (Figs. 1, 2). Lateral and apical extensions not observed. Spores bounded by thick bands in apical and side views (Fig. 2A-C). Spores $3.1 \pm 0.3$ (2.4-3.6) long, $4.7 \pm 0.3$ (4.3-5.4) wide and $3.8 \pm 0.3(3.4-4.3)$ thick. Four equal polar capsules convergent, pyriform in apical view, drop like in lateral view and occupying about third of valve volume (Fig. 2A, white arrows). Sutural lines visible in apical view but not in lateral view. Polar filament turns not visible but estimated using transmission electron microscopy. Polar capsules $1.6 \pm 0.3$ (1.2-1.8) long and $1.3 \pm 0.2(1.1-1.4)$ wide (Table 2).

Infected oocytes are easily identified under a stereomicroscope by their whitish colour and larger size (Fig. 3). Fresh oocytes, mounted on a microscopic slide and observed under light microscope, show the presence of mature myxospores packed inside the host cell (Fig. 3B). 


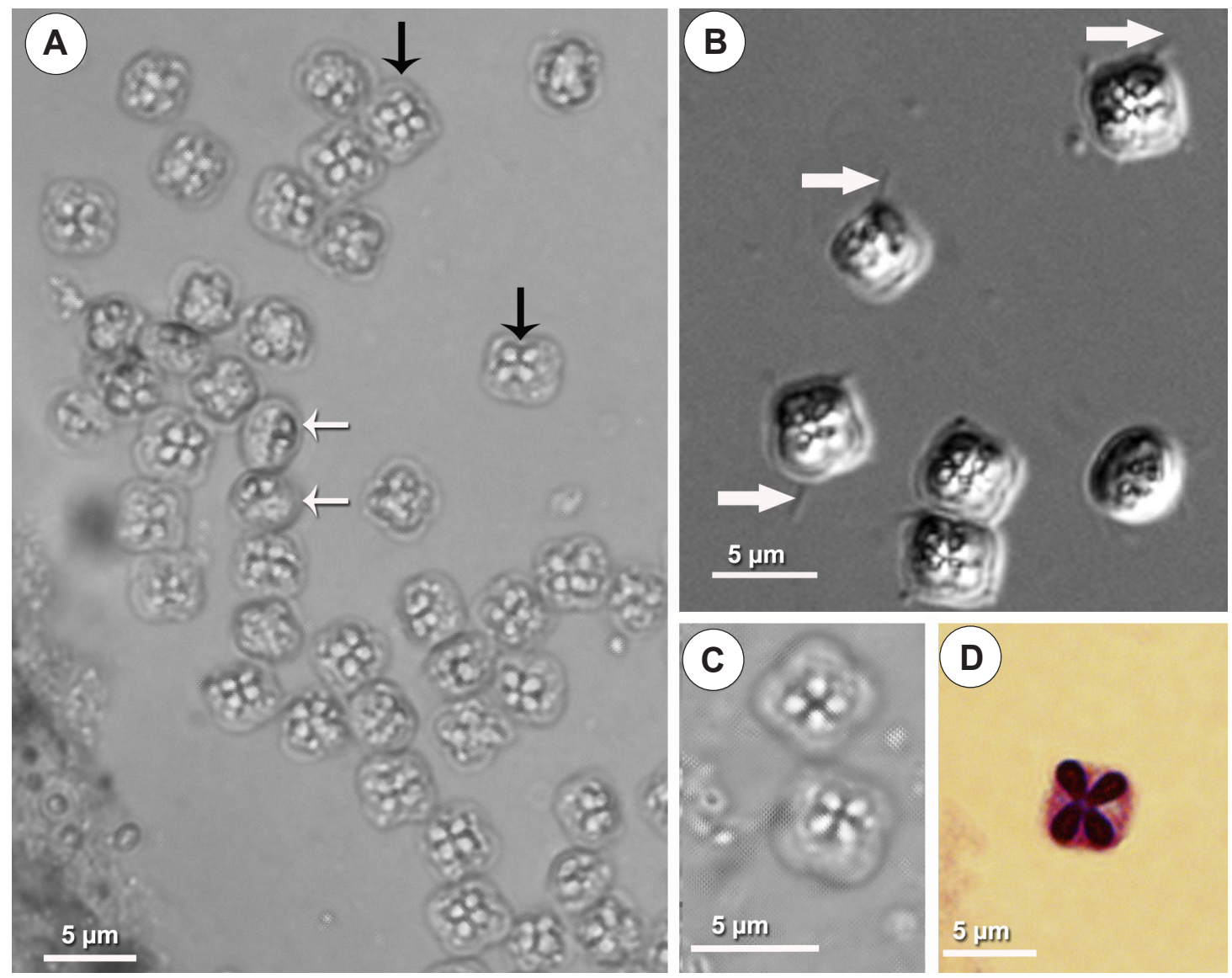

Fig. 2. Photomicrographs of mature spores of Kudoa saudiensis sp. n. infecting oocytes of Rastrelliger kanagurta. A-C - fresh smear showing spores in apical view (black arrows) and in side view (white arrows); B - phase contrast microphotograph showing extruded polar filaments (arrows); D - May-Grünwald Giemsa stained spores in apical view.
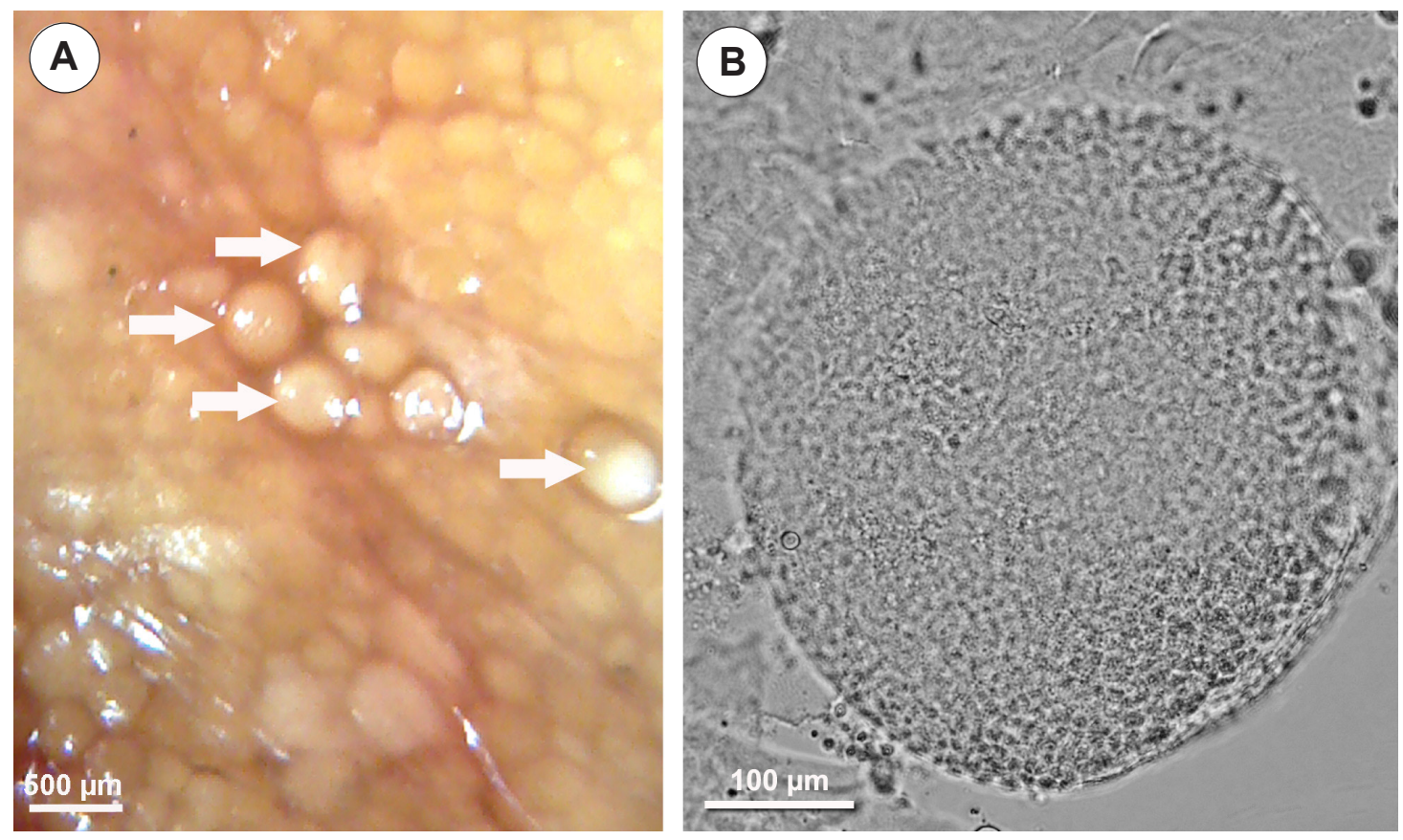

Fig. 3. Kudoa saudiensis sp. n. infecting oocytes of Rastrelliger kanagurta. A-superficial view of an ovary showing enlarged infected oocytes (arrows); B - fresh oocyte filled with myxospores observed under a light microscope. 
Table 2. Comparison of dimensions of Kudoa saudiensis sp. n. (in bold) with Kudoa spp. having four polar capsules and infecting ovaries or encountered in Scombridae species or in the Red Sea; range with mean \pm SD in parentheses.

\begin{tabular}{|c|c|c|c|c|c|c|c|}
\hline Kudoa species & Host (organ) & Locality & Width & Thickness & Length & $\begin{array}{l}\text { Polar capsule: } \\
\text { Length/width }\end{array}$ & Reference \\
\hline Kudoa saudiensis sp. n. & $\begin{array}{l}\text { Rastrelliger kanagurta } \\
\text { (Cuvier) } \\
\text { (ovary) }\end{array}$ & $\begin{array}{l}\text { Red Sea } \\
\text { (Saudi Arabia) }\end{array}$ & $\begin{array}{c}4.3-5.4 \\
(4.7 \pm 0.3)\end{array}$ & $\begin{array}{c}3.4-4.3 \\
(3.8 \pm 0.3)\end{array}$ & $\begin{array}{c}2.4-3.6 \\
(3.1 \pm 0.3)\end{array}$ & $\begin{array}{c}1.2-1.8 \\
(1.6 \pm 0.3) / \\
1.1-1.4 \\
(1.3 \pm 0.2)\end{array}$ & Present study \\
\hline $\begin{array}{l}\text { Kudoa azevedoi } \\
\text { Mansour, Thabet, Chourabi, } \\
\text { Harrath, Gtari, Al Omar et } \\
\text { Ben Hassine, } 2013\end{array}$ & $\begin{array}{l}\text { Trachurus trachurus } \\
\text { (Linnaeus) } \\
\text { (ovary) }\end{array}$ & $\begin{array}{l}\text { Mediterranean } \\
\text { Sea } \\
\text { (Tunisia) }\end{array}$ & $\begin{array}{c}4.0-5.2 \\
(4.6 \pm 0.4)\end{array}$ & $\begin{array}{c}3.3-4.8 \\
(3.8 \pm 0.5)\end{array}$ & $\begin{array}{c}3.0-4.2 \\
(3.5 \pm 0.4)\end{array}$ & $\begin{array}{l}1.5-2.0(1.5) / \\
0.5-1.0(0.8)\end{array}$ & $\begin{array}{l}\text { Mansour et al. } \\
2013\end{array}$ \\
\hline $\begin{array}{l}\text { Kudoa crumena } \\
\text { Iversen, Van et Meter, } 1967\end{array}$ & $\begin{array}{l}\text { Scomberomorus maculatus } \\
\text { (Mitchill) } \\
\text { (skeletal muscles) }\end{array}$ & $\begin{array}{l}\text { Atlantic Ocean, } \\
\text { South Florida }\end{array}$ & $\begin{array}{l}9.3-10.4 \\
(9.9)\end{array}$ & $\begin{array}{l}8.2-9.7 \\
(9.0)\end{array}$ & $\begin{array}{l}6.8-8.2 \\
(7.5)\end{array}$ & $\begin{array}{l}3.2-4.6(4.0) / \\
2.1-2.9(2.5)\end{array}$ & $\begin{array}{l}\text { Iversen and Van } \\
\text { Meter } 1967\end{array}$ \\
\hline $\begin{array}{l}\text { Kudoa nova } \\
\text { Kovaleva, Schulman et } \\
\text { Yakovlev, } 1967\end{array}$ & $\begin{array}{l}\text { Thunnus obesus (Lowe), } \\
\text { Trachurus spp., Neogobius } \\
\text { spp., Gobius spp., and others } \\
\text { (skeletal muscles) }\end{array}$ & $\begin{array}{l}\text { Atlantic Ocean, } \\
\text { Black Sea, } \\
\text { Mediterranean } \\
\text { Sea }\end{array}$ & $\begin{array}{l}5.1-7.7 \\
(6.2)\end{array}$ & - & $\begin{array}{l}5.1-7.7 \\
(6.2)\end{array}$ & $\begin{array}{l}1.3-2.6 \\
(1.8)\end{array}$ & $\begin{array}{l}\text { Moran et al.1999 } \\
\text { Kovaleva et al. } \\
\text { 1979; Campbell } \\
2005\end{array}$ \\
\hline $\begin{array}{l}\text { Kudoa ovivora } \\
\text { Swearer et Robertson, } 1999\end{array}$ & $\begin{array}{l}\text { Thalassoma bifasciatum } \\
\text { (Bloch) } \\
\text { (ovary) }\end{array}$ & $\begin{array}{l}\text { Sea of Azov } \\
\text { Caribbean }\end{array}$ & $\begin{array}{c}6.7-8.3 \\
(7.7)\end{array}$ & $\begin{array}{l}5.8-7.7 \\
(6.9)\end{array}$ & $\begin{array}{l}5.0-7.5 \\
(6.5)\end{array}$ & $\begin{array}{l}1.7-2.5(2.1) / \\
1.3-1.7(1.5)\end{array}$ & $\begin{array}{l}\text { Swearer and } \\
\text { Robertson } 1999\end{array}$ \\
\hline $\begin{array}{l}\text { Kudoa pagrusi } \\
\text { Al Quraishy, Koura, Abdel- } \\
\text { Baki, Bashtar, El Deed, Al } \\
\text { Rasheid et Abdel Ghaffar, } \\
2008\end{array}$ & $\begin{array}{l}\text { Pagrus pagrus } \\
\text { (Linnaeus) } \\
\text { (heart muscles) }\end{array}$ & Red Sea & $\begin{array}{c}5.8-7.2 \\
(6.4 \pm 0.4)\end{array}$ & $\begin{array}{c}5.8-7.2 \\
(6.4 \pm 0.4)\end{array}$ & $\begin{array}{c}6.5-8.6 \\
(7.0 \pm 0.8)\end{array}$ & $\begin{array}{c}2.6-4.2 \\
(3.7 \pm 0.3) / \\
1.0-1.8 \\
(1.5 \pm 0.2)\end{array}$ & $\begin{array}{l}\text { Al-Quraishy et } \\
\text { al.2008 }\end{array}$ \\
\hline $\begin{array}{l}\text { Kudoa quraishii } \\
\text { Mansour, Harrath, Abd- } \\
\text { Elkader, Alwasel, Abdel- } \\
\text { Baki et Al Omar, } 2014\end{array}$ & $\begin{array}{l}\text { Rastrelliger kanagurta } \\
\text { (skeletal muscles) }\end{array}$ & $\begin{array}{l}\text { Red Sea, } \\
\text { Arabian Gulf } \\
\text { (Saudi Arabia) }\end{array}$ & $\begin{array}{c}5.9-6.3 \\
(6.1 \pm 0.4)\end{array}$ & $\begin{array}{c}5.3-5.7 \\
(5.5 \pm 0.3)\end{array}$ & $\begin{array}{c}4.1-4.4 \\
(4.3 \pm 0.4)\end{array}$ & $\begin{array}{c}1.9-2.3 \\
(2.1 \pm 0.3) / \\
1.1-1.5 \\
(1.3 \pm 0.2)\end{array}$ & $\begin{array}{l}\text { Mansour et al. } \\
(2014)\end{array}$ \\
\hline $\begin{array}{l}\text { Kudoa scomberi } \\
\text { Li, Sato, Tanaka, Ohnishi } \\
\text { et Kamata Sugita-Konishi, } \\
2013\end{array}$ & $\begin{array}{l}\text { Scomber japonicus } \\
\text { Houttuyn } \\
\text { (skeletal muscles) }\end{array}$ & & $\begin{array}{l}8.2-10.5 \\
(9.2)\end{array}$ & $\begin{array}{l}7.0-8.8 \\
(8.1)\end{array}$ & $\begin{array}{l}6.1-6.8 \\
(6.4)\end{array}$ & $\begin{array}{l}2.5-3.4(2.9) / \\
1.3-2.0(1.6)\end{array}$ & Li et al. 2013 \\
\hline $\begin{array}{l}\text { Kudoa sebastea } \\
\text { Aseeva, } 2004\end{array}$ & $\begin{array}{l}\text { Sebastes minor } \\
\text { Barsukov } \\
\text { (skeletal muscles) }\end{array}$ & Japan & $7.3-8.2$ & $5.0-5.5$ & $5.4-5.6$ & $2.0-2.2 / 0.8-1.0$ & Aseeva 2004 \\
\hline $\begin{array}{l}\text { Kudoa shiomitsu } \\
\text { Egusa et Shiomitsu, } 1983\end{array}$ & $\begin{array}{l}\text { Thunnus orientalis } \\
\text { (Temminck et Schlegel), } \\
\text { Takifugu rubripes } \\
\text { (Temminck et Schlegel) } \\
\text { (heart muscles) }\end{array}$ & $\begin{array}{l}\text { Pacific Ocean } \\
\text { Japan }\end{array}$ & $\begin{array}{c}8.6-9.8 \\
(9.4 \pm 0.3)\end{array}$ & $\begin{array}{c}6.7-7.5 \\
(7.2 \pm 0.3)\end{array}$ & $\begin{array}{c}5.6-6.8 \\
(6.2 \pm 0.4)\end{array}$ & $\begin{array}{c}2.5-3.0 \\
(2.8 \pm 0.2) / \\
1.0-1.4 \\
(1.3 \pm 0.1)\end{array}$ & $\begin{array}{l}\text { Egusa and } \\
\text { Shiomitsu 1983; } \\
\text { Zhang et al. } 2010\end{array}$ \\
\hline $\begin{array}{l}\text { Kudoa thunni } \\
\text { Matsukane, Sato, Tanaka, } \\
\text { Kamata et Sugita-Konishi, } \\
2011\end{array}$ & $\begin{array}{l}\text { Thunnus alalunga } \\
\text { (Bonnaterre) } \\
\text { (skeletal muscles) }\end{array}$ & Pacific Ocean & $\begin{array}{l}9.2-9.9 \\
(9.5)\end{array}$ & $\begin{array}{l}7.7-9.0 \\
(8.3)\end{array}$ & $\begin{array}{l}6.4-6.6 \\
(6.5)\end{array}$ & $\begin{array}{l}2.2-2.9(2.5) / \\
1.9-2.2(2.1)\end{array}$ & $\begin{array}{l}\text { Matsukane et al. } \\
2011\end{array}$ \\
\hline
\end{tabular}

\section{TEM observation}

Mature spores with four shell valves and four polar capsules (Fig. 4). Three coils of polar filament observed. Shell valves not overlapping and junctions visible (Fig. 4A,B). Sutural lines also visible (Fig. 4C). Mature spores showed thickened material deposited in the apex; this is probably collagen material facilitating projection of the polar filament (Fig. 4B,C).

\section{Histological observation of ovaries}

Examination of serial sections of infected ovaries showed that infected oocytes were larger than uninfected ones. Large numbers of plasmodia occupying the cytoplasm are separated by a septum-like structure (Fig. 5A,B). For newly parasitised oocytes, infection started at the periphery, at the level of the basal membrane towards the centre, before developing broad-based unbranched plasmodia. Yolk granules were trapped in the centre or between plasmodia (Fig. 5A,B). Infected oocytes are significantly larger than uninfected ones, with mean diameter of infected oocytes $345-583 \mu \mathrm{m}(438 \pm 61 \mu \mathrm{m})$ compared to $148-283 \mu \mathrm{m}(224 \pm 32 \mu \mathrm{m})$ in uninfected ones.
In all examined sections no immune response following infection with $K$. saudiensis was observed. Oocytes were limited by their membrane, appearing similar to uninfected ones (Fig. 5C).

Type host: Rastrelliger kanagurta (Cuvier) (Perciformes: Scombridae).

Type locality: Jeddah coast $\left(21^{\circ} 32^{\prime} 36^{\prime \prime} \mathrm{N} ; 39^{\circ} 10^{\prime} 22^{\prime \prime E}\right)$, Red Sea, Saudi Arabia.

Site of infection: Oocytes.

Prevalence: $20 \%(7 / 35)$.

Material deposited: One slide of serial histological sections of infected tissue (ZS121) and one slide of Giemsa stained smear of spores (ZS122) were deposited in the Protists Collection of the Muséum nationale de historie naturelle, Paris, France.

Etymology: The specific name $K$. saudiensis refers to the country from which the parasite is reported (Saudi Arabia).

D N A s equences: SSU and LSU rDNA sequences were deposited in GenBank under the accession numbers, KF830719 and KF830720, respectively. 

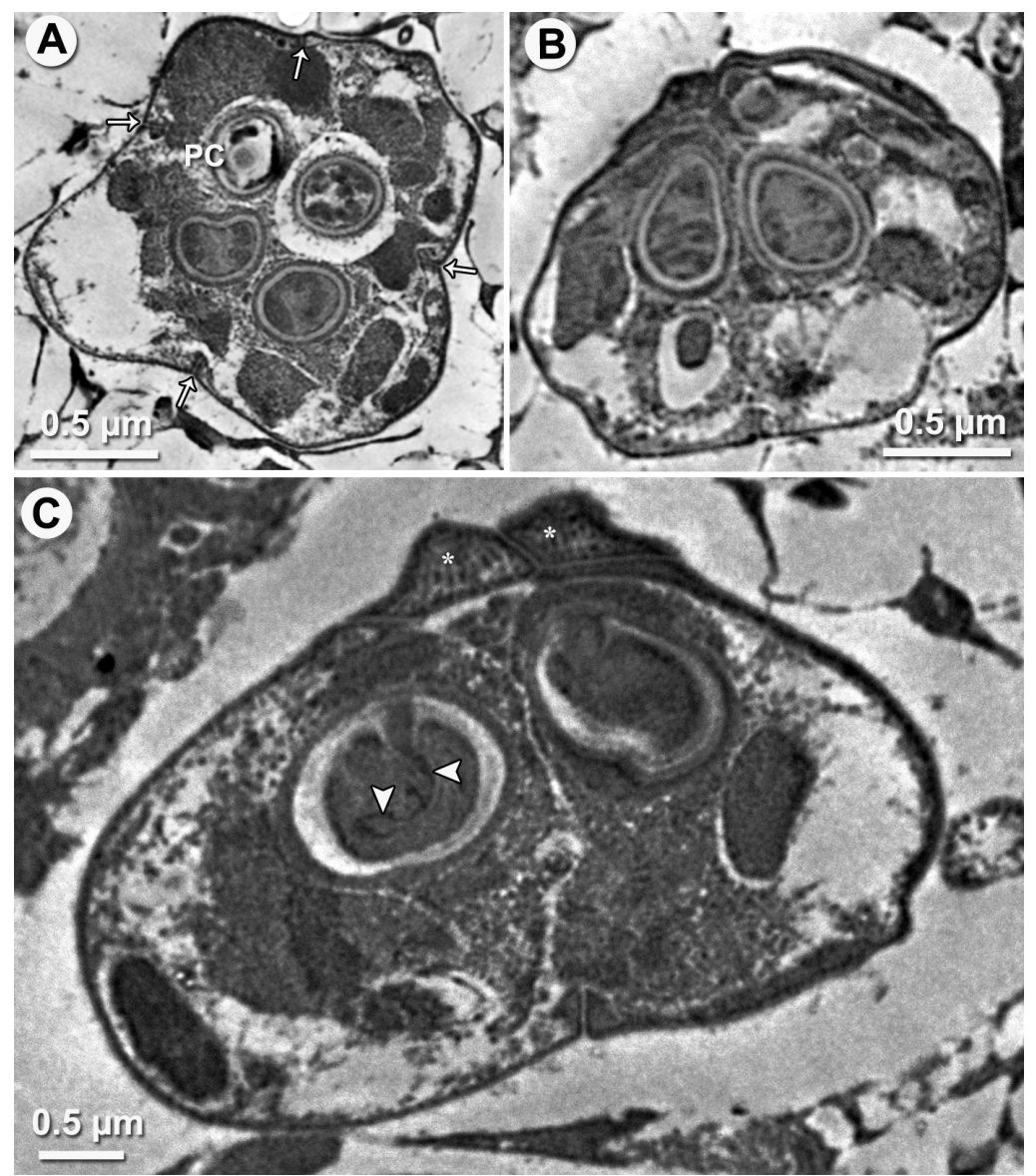

Fig. 4. Transmission electron micrographs of a mature spore of Kudoa saudiensis sp. $\mathrm{n}$. from the oocyte of Rastrelliger kanagurta. A - cross section in apical view showing the four polar capsules (pc), the junctions of the four shell valves (arrows) are not overlapping; B, C - longitudinal sections of a mature spore through the two polar capsules showing coiled polar filament and deposited material, probably collagen fibres (stars) in the apical part of the mature spore.
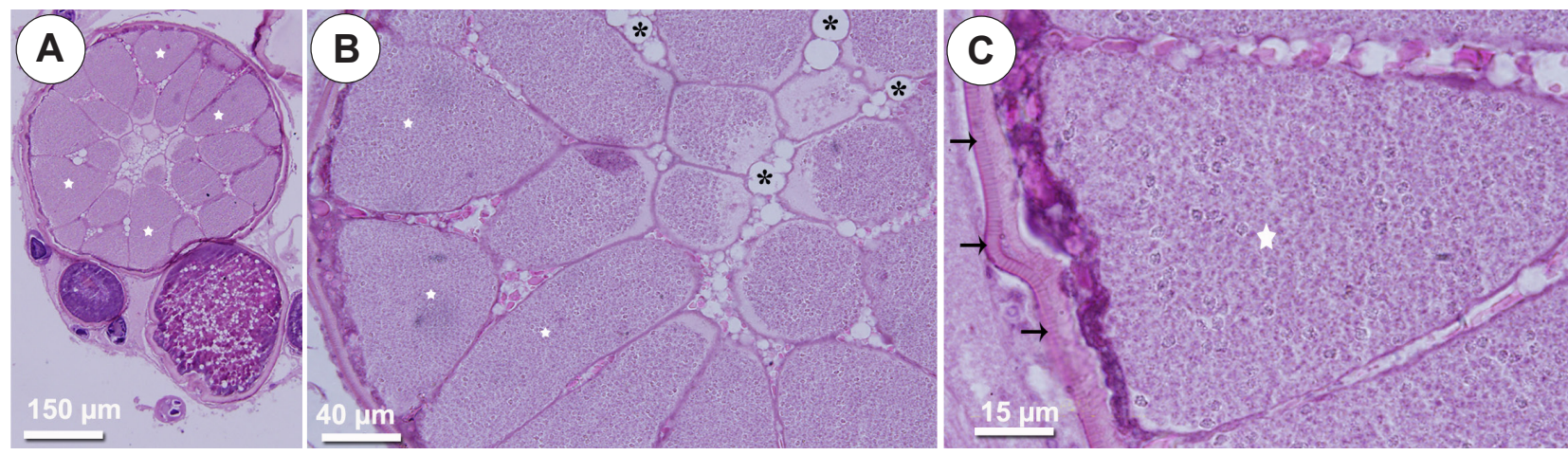

Fig. 5. Different magnifications of stained histological sections of oocytes of Rastrelliger kanagurta infected with Kudoa saudiensis sp. n. A-hypertrophied infected oocyte showing plasmodia (white stars) between the inner membrane and the nucleus. The sectioned oocyte appears similar to an orange fruit, with the plasmodia arranged in a segment formation; $\mathbf{A}, \mathbf{B}-$ in the infected oocyte, yok globules (black stars) are trapped between plasmodia and in the centre of the cell; $\mathbf{C}$ - the membrane of the infected oocyte is unchanged and appears similar to that of an uninfected cell (black arrows).

Remarks. Among the ninety five Kudoa spp. described previously, only two of them have been reported thus far in the ovary of the infected fishes. Kudoa saudiensis sp. $\mathrm{n}$. is thus the third species reported infecting the ovary. Based on the host, site of infection and spore morphometrics, ten species of Kudoa are found to resemble the present form (Table 2). The parasite described herein as a new spe- cies possesses quite smaller dimensions of spores than K. crumena Iversen, Van et Meter, 1967, K. nova Kovaleva, Schulman et Yakovlev, 1967, K. shiomitsu Egusa et Shiomitsu, 1983, K. ovivora Swearer et Robertson, 1999, K. sebastea Aseeva, 2004, K. pagrusi Al Quraishy, Koura, Abdel-Baki, Bashtar, El Deed, Al Rasheid et Abdel Ghaffar, 2008, K. thunni Matsukane, Sato, Tanaka, Kamata et 


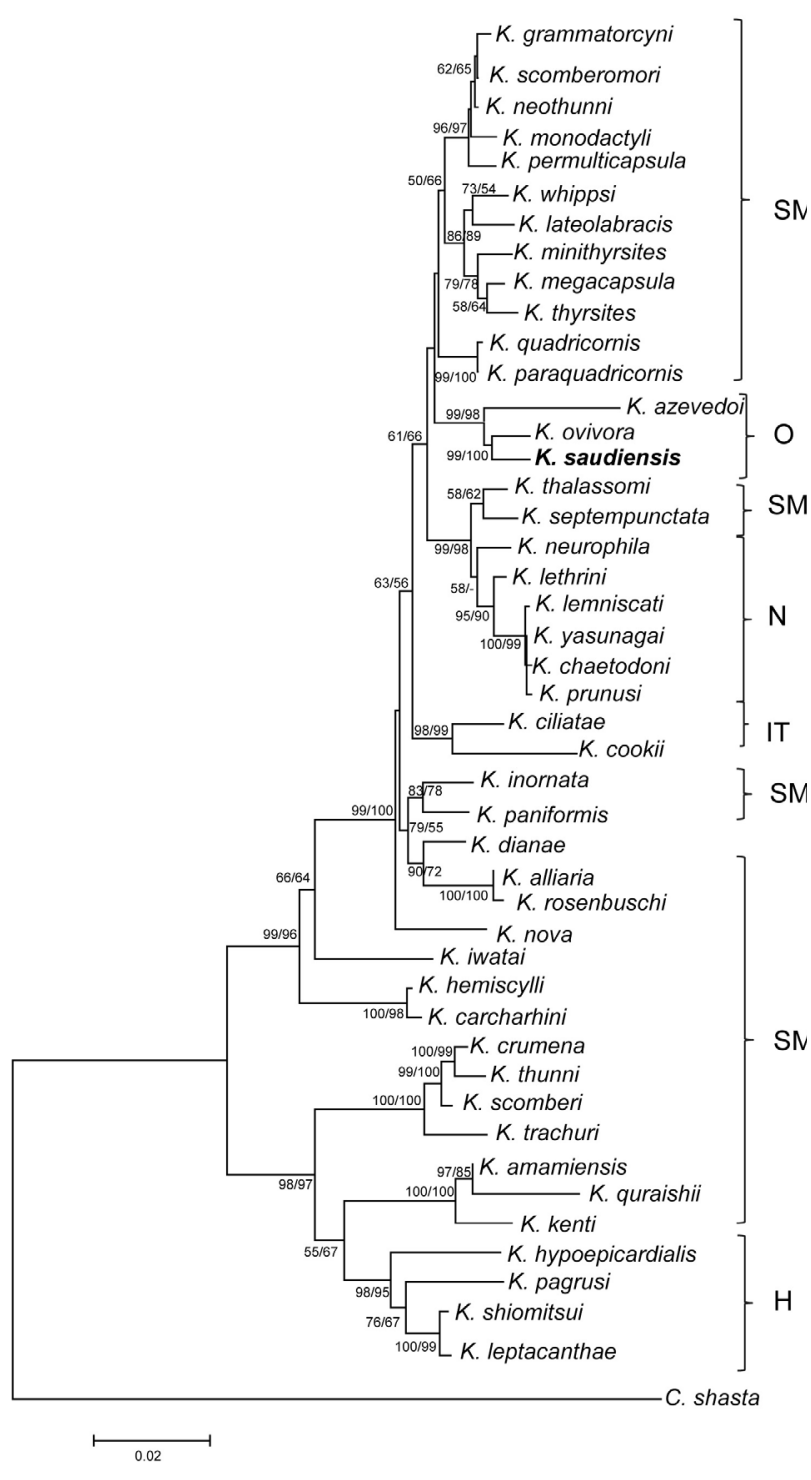

Fig. 6. Phylogenetic tree of Kudoa spp. based on maximum likelihood ( $L n=-7568.21)$ using the SSU rDNA data set showing the close association between Kudoa saudiensis sp. n. (in bold), $K$. ovivora and $K$. azevedoi. Bootstrap values from Maximum likelihood/maximum parsimony analysis are indicated at each node. Values below $50 \%$ are indicated by dashes. Ceratomyxa shasta was used as outgroup. Abbreviations: $\mathrm{H}$ - heart tissue; IT - intestine tissue; $\mathrm{N}$ - nervous system; O - ovary; SM - skeletal muscles. The scale bar shows the number of changes per site.

Sugita-Konishi, 2011 and K. scomberi Li, Sato, Tanaka, Ohnishi et Kamata Sugita-Konishi, 2013 (see Iversen and Van Meter 1967, Kovaleva et al. 1979, Egusa and Shiomitsu 1983, Swearer and Robertson 1999, Al-Quraishy et al. 2008, Matsukane et al. 2011, Li et al. 2013). In addition, all these pervious species were described from muscles except K. ovivora. Although K. quraishii (see Mansour et al. 2014) was described from the same host ( $R$. kanagurta), it was different in having larger spores and was described from the skeletal muscle. In the same way, K. azevedoi Mansour, Thabet, Chourabi, Harrath, Gtari, Al Omar et Ben Hassine, 2013 described from the ovary, differs in having slightly thinner and shorter spores with smaller polar capsules (Mansour et al. 2013). In addition, the polysporous

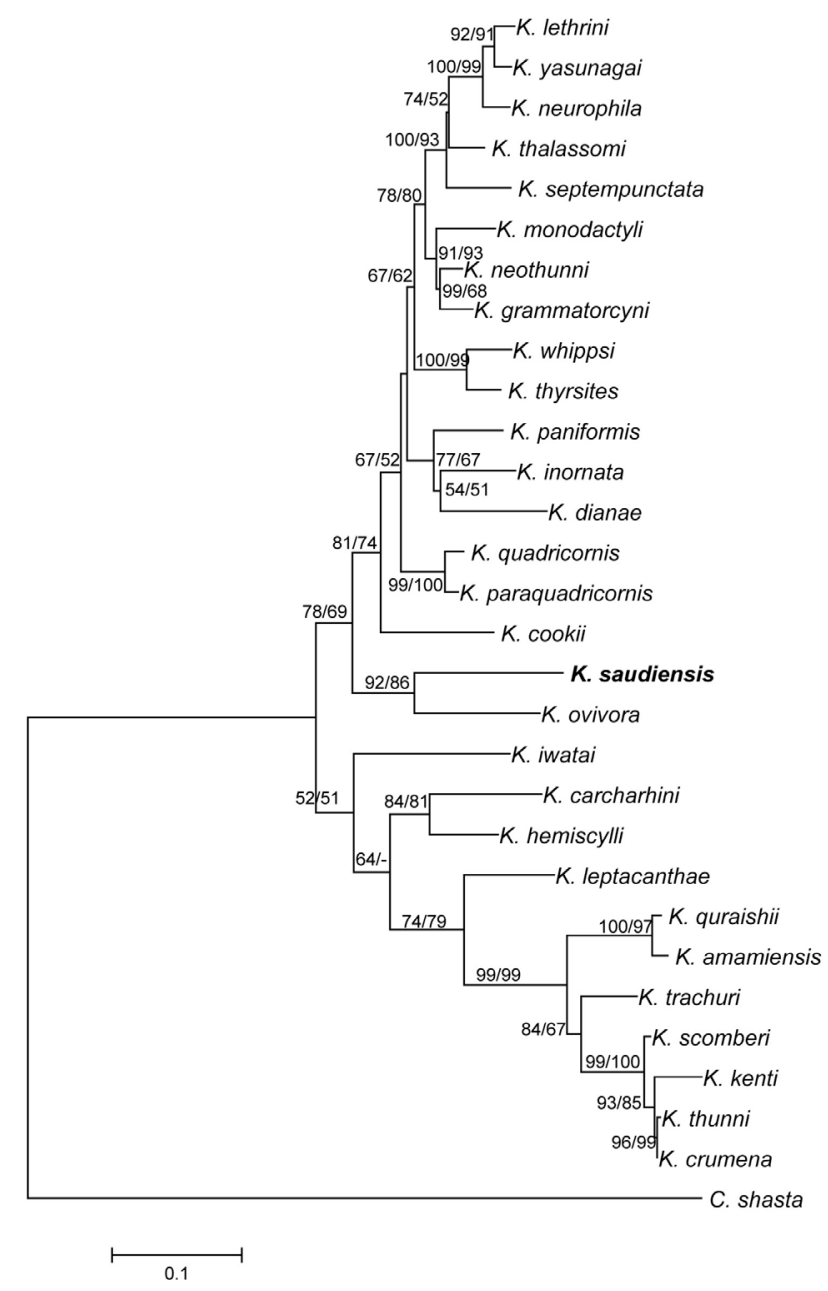

Fig. 7. Maximum likelihood phylogenetic tree obtained from LSU rDNA aligned Kudoa sequences. Kudoa saudiensis sp. n. (in bold) is closely associated with $K$. ovivora. The tree was obtained with the highest log likelihood (-6021.6757). Bootstrap values from Maximum likelihood/maximum parsimony analysis are indicated at each node. Values below $50 \%$ are indicated by dashes. Ceratomyxa shasta was used as outgroup. The scale bar shows the number of changes per site.

plasmodia of $K$. saudiensis were vesicular and not tubular and ramified as observed in $K$. azevedoi. Based on these differences, we believe that the Kudoa we describe here is a distinct form.

\section{Phylogenetic analyses}

Sequences of $1557 \mathrm{bp}$ of the SSU rDNA and $735 \mathrm{bp}$ of the LSU rDNA (GeneBank accession number KF830719 and KF830720, respectively) of K. saudiensis sp. n. were used for phylogenetic analyses. Maximum likelihood and maximum parsimony trees based on the SSU rDNA sequences were similar and showed a close association between the present new species and the two other known Kudoa spp. infecting oocytes, grouping them in the same cluster with a bootstrap support of $99 \% / 98 \%$ (Fig. 6). The Kimura-2 parameter distance was 0.015 for $K$. ovivora and 0.02 for $K$. azevedoi, corresponding to a similarity of $98.5 \%$ and $98 \%$, respectively (Table 1 ). 
The new Kudoa species differed from $K$. ovivora and $K$. azevedoi by 26 bp (12 transitions and 14 transversions) and 52 bp (28 transitions and 24 transversions), respectively. The percentage of similarity between $K$. quraishii and K. saudiensis is $88.91 \%$. Topology of the phylogenetic LSU rDNA-based tree was similar to the SSU rDNA-based tree. A clade formed with the new Kudoa species and K. ovivora is supported by a bootstrap of $92 \%$ (Fig. 7). The highest percentage of similarity was also observed with $K$. ovivora $(81.01 \%)$. The LSU rDNA sequence of $K$. azevedoi, which was present in the SSU rDNA-based tree, is not yet available in GenBank.

\section{DISCUSSION}

Species of Kudoa are rarely reported infecting ovaries with only two species having been found parasitising oocytes; Kudoa ovivora has been reported from the eggs of seven labroid species from the Caribbean coast of Panama (Swearer and Robertson 1999), and K. azevedoi was described from oocytes of the Atlantic horse mackerel Trachurus trachurus (Linnaeus) off the Tunisian coast (Mansour et al. 2013). These two species were both reported to form tubular and ramified plasmodia within infected oocytes.

Recently, K. quraishii infecting the skeletal muscle of the Indian mackerel, Rastrelliger kanagurta (Perciformes, Scombridae) in the Red Sea and Arabian Gulf has been described by Mansour et al. (2014). We report herein a new species $K$. saudiensis sp. n., infecting oocytes of the same host, R. kanagurta, from the Red Sea. Infections with $K$. saudiensis occur only in mature females and were never observed in males or in fish infected with K. quraishii.

In the Red Sea, in addition to K. quraishii, four other $\mathrm{Ku}$ doa species have been reported, K. aegyptia Koura 2000, K. pagrusi and Kudoa sp. infecting the hearts of Rhabdosargus haffara (Forsskål), Pagrus pagrus (Linnaeus) and Plectropomus maculates (Bloch), respectively (Koura 2000, Al-Quraishy et al. 2008, Abdel-Ghaffar et al. 2012) and K. iwatai Egusa et Shiomitsu, 1983 reported by Diamant et al. (2005) in the skeletal muscles and other organs of the European sea bass Dicentrarchus labrax Linnaeus. Compared to the above mentioned species $K$. saudiensis is easily distinguished by its smaller size and the morphology of its spores. In fish of the family Scombridae, numerous myxosporeans with four shell valves have been reported. With the exception of $K$. shiomitsu reported from the heart muscle tissue, all other species have been reported infecting skeletal muscles and have larger spores than K. saudiensis (Table 2). The only species infecting Scombrid fish that would be in the range of $K$. saudiensis is $K$. nova, reported from Thunnus obesus (Lowe) but also from at least 22 other host species worldwide (Moran and Kent 1999, Burger and Adlard 2011).

The histopathological study shows that like $K$. azevedoi and $K$. ovivora, $K$. saudiensis develops within plasmodia inside the oocytes. However, plasmodia of $K$. saudiensis are vesicular, not tubular and ramified as reported for $K$. azevedoi and $K$. ovivora. According to Mansour et al.
(2013), infection of newly infected oocytes starts at the periphery. As reported for $K$. azevedoi and $K$. ovivora infecting ovaries, the host cell seems to remain viable even though it is packed with the parasite. The membranes of the infected oocytes are similar to those of uninfected ones without any deposited material or obvious immune reaction (Mansour et al. 2013). The yolk granules are fairly numerous supporting the functionality of the host cell. This observation was described for $K$. azevedoi by Mansour et al. (2013) as a xenoma-like structure where the parasite and the host cell form a xenoparasitic complex.

In the genus Kudoa, xenoma-like formations were observed in two species, $K$. thyrsites Gilchrist, 1924 and $K$. neurophila Grossel, Dyková, Handlinger et Munday, 2003 by Moran et al. (1999) and Grossel (2005). The xenoma-like structures induced as a consequence of intraoocyte development of $K$. saudiensis as well as $K$. azevedoi, and presumably in the case of $K$. ovivora, are similar. They are characterised by an enlargement of the cytoplasm without further modifications at the periphery but no precise data were obtained about the nucleus of the host cell. Further investigations, mainly at the ultrastructural level are required in order to elucidate this particular structure.

The effect of the parasite on the fecundity of the host is difficult to assess for wild fish. However, as reported for K. ovivora infection (Swearer and Robertson 1999), we believe that infected oocytes are sterile, but this sterility could not affect uninfected oocytes. Moreover, in the sequential hermaphrodite, the fish Thalassoma bifasciatum (Bloch), K. ovivora influences sex allocation of its host. Thus, it was suggested that females infected by this parasite not only have a lower reproductive success, but also change sex earlier and at a smaller size than uninfected ones (Schärer and Vizoso 2003). Such situation could also lead to a quick loss of the parasite as the ovarian tissue will be replaced by testes. In the case of $K$. saudiensis, further studies are important to assess the potential pathogenic effect of the parasite on infected oocytes and on the reproductive effort of the host, and to characterise the parasite's life cycle and its mode of transmission.

Molecular analysis, based on the partial sequence of the SSU rDNA gene, confirmed that the present Kudoa is a new species exhibiting the highest percentage of sequence similarity $(98.5 \%)$ with $K$. ovivora (Table 1$)$. The new species has $11.09 \%$ of divergence from $K$. quraishii encountered in the same host species. Phylogenetic analysis shows a close association of $K$. saudiensis, $K$. ovivora and $K$. azevedoi in well supported clade. Molecular analysis based on the LSU rDNA data set confirmed the close association of $K$. ovivora and $K$. saudiensis as shown by SSU rDNA data.

Thus, whereas these three species infect three hosts belonging to three different families from three different and distant ecosystems, they appear closely phylogenetically related. Perhaps, identification of other new species infecting oocytes may clarify this relationship. Clustering according to the tissue tropism is well known for many $K u$ doa parasites and is one of the main trends in clustering of myxosporeans (Fiala 2006). We have also observed relatedness of species of Kudoa infecting ovaries with those 
infecting the heart, brain, nervous tissue and intestine. $\mathrm{Ku}$ doa infecting skeletal muscles, however, are distributed in different clades throughout the main Kudoa groups. In this context, further investigations are required in order to attempt to determine the molecular factors controlling the tissue specificity of these Kudoa parasites.
Acknowledgements. The authors extend their appreciation to the Deanship of Scientific Research at King Saud University for funding the work through the research group project NoRGPVPP-254. We are grateful to Mark Freeman, Malaya University, for English corrections of the manuscript. Authors are grateful to anonymous reviewers for their valuable comments that improved the manuscript.

\section{REFERENCES}

Abdel-Ghaffar F., Morsy K., Mehlhorn H., Bashtar A.R., Shazly M.A., SaAd A.H., Abdel-Gaber R. 2012: First report of Kudoa species (Myxozoa: Kudoidae) infecting the spotted coral grouper Plectropomus maculates from the Red Sea. A light and ultrastructural study. Parasitol. Res. 111: 1579-1585.

Adlard R.D., Bryant M.S., Whipps C.M., Kent M.L. 2005: Multivalvulid myxozoans from eastern Australia: three new species of Kudoa from scombrid and labrid fishes of the Great Barrier Reef, Queensland, Australia. J. Parasitol. 91: 1138-1142.

Al-Quraishy S., Koura E., Abdel-Baki A.S., Bashtar A.R., El Deed N., Al Rasheid K., Abdel Ghaffar F. 2008: Light and electron microscopic studies on Kudoa pagrusi sp. n. (Myxosporea: Multivalvulida) infecting the heart of sea bream Pagrus pagrus (L.) from the Red Sea. Parasitol. Res. 102: 205-209.

Aseeva N.L. 2004: New species of Myxosporea from genus Kudoa (Myxosporea, Multivalvulida) found in muscles of some fishes of the Sea of Japan. Vestnik. Zoologii 38: 75-77.

Burger M.A., Adlard R.D. 2010a: Four new species of Kudoa Meglitsch, 1947 (Myxosporea: Multivalvulida) from Australia with recommendations for species descriptions in the Kudoidae. Parasitology 137: 793-814.

Burger M.A., AdLard R.D. 2010b: Phenotypic variation in a significant spore character in Kudoa (Myxosporea: Multivalvulida) species infecting brain tissue. Parasitology 137: 1759-1772.

Burger M.A., Adlard R.D. 2011: Low host specificity in the Kudoidae (Myxosporea: Multivalvulida) including 17 new host records for Kudoa thalassomi. Folia Parasitol. 58: 1-16.

Burger M.A., Barnes A.C., Adlard R.D. 2008: Wildlife as reservoirs for parasites infecting commercial species: host specificity and a redescription of Kudoa amamiensis from teleost fish in Australia. J. Fish Dis. 31: 835-844.

Campbell N. 2005. The myxosporean parasitofauna of the Atlantic horse mackerel, Trachurus trachurus (L.) in the North-East Atlantic Ocean and Mediterranean. Sea Acta Parasitol. 50: 97-101

Canning E.U., Okamura B. 2004: Biodiversity and evolution of the Myxozoa. Adv. Parasitol. 56: 43-131.

Diamant A., Ucko M., Paperna I., Colorni A., Lipshitz A. 2005: Kudoa iwatai (Myxosporea: Multivalvulida) in wild and cultured fish in the Red Sea: redescription and molecular phylogeny. J. Parasitol. 91: 1175-1189.

Egusa S. 1986: The order Multivalvulida Shulman, 1959 (Мухоzoa; Myxosporea): a review. Fish Pathol. 21: 261-274.

Egusa S., Nakajima K. 1980: Kudoa amamiensis sp. n. (Myxosporea: Multivalvulida) found in cultured yellowtails and wild damselfishes from Amami-Ohshima and Okinawa, Japan. Bull. Jpn. Soc. Sci. Fish. 46: 1193-1198

Egusa S., Shiomitsu T. 1983. Studies on myxosporidian parasites of the genus Kudoa found in marine fish cultured in Japan. Fish Pathol. 18: 163-71.

Eiras J.C., Saraiva A., Cruz C. 2014: Synopsis of the species of Kudoa Meglitsch, 1947 (Myxozoa: Myxosporea: Multivalvulida). Syst. Parasitol. 87: 153-180.

Fiala I. 2006: The phylogeny of Myxosporea (Myxozoa) based on small subunit ribosomal RNA gene analysis. Int. J. Parasitol. 36: $1521-1534$

Grossel G. 2005: Kudoa neurophila in striped trumpeter: identification, diagnostic development and histopathology. $\mathrm{PhD}$ thesis, University of Tasmania, Tasmania, 137 pp.
Heiniger H., Cribb T.H., Adlard R.D. 2013: Intra-specific variation of Kudoa spp. (Myxosporea: Multivalvulida) from apogonid fishes (Perciformes), including the description of two new species, K. cheilodipteri n. sp. and K. cookii n. sp., from Australian waters. Syst. Parasitol. 84: 193-215.

Ishimaru K., Matsuura T., Tsunemoto K., Shirakashi S. 2014: Seasonal monitoring of Kudoa yasunagai from sea water and aquaculture water using quantitative PCR. Dis. Aquat. Org. 108: 45-52.

Iversen E.S., Van Meter N.N. 1967: A new myxosporidian (Sporozoa) infecting the Spanish mackerel. Bull. Mar. Sci. 17: 268-273.

Kent M.L., Andree K.B., Bartholomew J.L., El-Matbouli M., Desser S.S., Devlin R.H., Feist S.W., Hedrick R.P., Hoffmann R.W., Khattra J., Hallett S.L., Lester R.J., Longshaw M., Palenzeula O., Siddall M.E., Xiao C. 2001: Recent advances in our knowledge of the Myxozoa. J. Euk. Microbiol. 48: 395-413.

Kent M.L., Margolis L., Whitaker D.J., Hoskins G.E., McDONALD T.E. 1994: Review of Myxosporea of importance in salmonid fisheries and aquaculture in British Columbia. Folia Parasitol. 41: 27-37.

Koura E.A. 2000: Kudoa aegyptia sp. n. (Myxozoa: Multivalvulida), in the heart muscles of haffara fish Rhabdosargus haffara. Egypt. J. Zool. 34: 1-26.

Kovaleva A.A., Shulman S.S., Yakovlev V.N. 1979: [Myxosporidia of the genus Kudoa (Myxosporidia, Multivalvulida) of the Atlantic Ocean basin]. Tr. Zool. Inst. Akad. Nauk. SSSR. 87: 42-64. (In Russian.)

Larkin M.A., Blackshields G., Brown N.P., Chenna R., Mcgettigan P.A., Mcwilliam H., Valentin F., Wallace I.M., Wilm A., Lopez R., Thompson J.D., Gibson T.J., HigGINS D.G. 2007: Clustal W and Clustal X version 2.0. Bioinformatics 23: 2947-2948.

Levsen A., Jorgensen A., Mo T.A. 2008: Occurrence of postmortem myoliquefactive kudoosis in Atlantic mackerel, Scomber scombrus L., from the North Sea. J. Fish Dis. 31: 601-611.

Li Y., Sato H., Tanaka S., Ohnishi T., Kamata Y., SugitaKonishi Y. 2013. Characterization of the ribosomal RNA gene of Kudoa neothunni (Myxosporea: Multivalvulida) in tunas (Thunnus spp.) and Kudoa scomberi $\mathrm{n}$. sp. in a chub mackerel (Scomber japonicus). Parasitol. Res. 112: 1991-2003.

Lom J., Arthur J. R. 1989. A guideline for the preparation of species descriptions in Myxosporea. J. Fish Dis. 12: 151-156.

Loм J., DyкоvÁ I. 2006: Myxozoan genera: definition and notes on taxonomy, life-cycle terminology and pathogenic species. Folia Parasitol. 53: 1-36.

Lundy C.J., Moran P., Rico C., Milner R.S., Hewitt G.M. 1999: Macrogeographical population differentiation in oceanic environments: a case study of European hake (Merluccius merluccius), a commercially important fish. Mol. Ecol. 8: 1889-1898.

Mansour L., Harrath A.H., AbD-Elkader O.H., Alwasel S., Abdel-Baki A.A., Al Omar S.Y. 2014: Structural and molecular characterization of Kudoa quraishii n. sp. from the trunk muscle of the Indian mackerel Rastrelliger kanagurta (Perciformes, Scombridae) in Saudi Arabia coasts. Parasitol. Res. 113: 1361-1370.

Mansour L., Thabet A., Chourabi K., Harrath A.H., Gtari M., Al Omar S.Y., Ben Hassine O.K. 2013: Kudoa azevedoi 
n. sp. (Myxozoa, Multivalvulida) from the oocytes of the Atlantic horse mackerel Trachurus trachurus (Perciformes, Carangidae) in Tunisian coasts. Parasitol. Res. 112: 1737-1747.

Matsukane Y., Sato H., Tanaka S., Kamata Y., Sugita-KonISHI Y. 2011. Kudoa iwatai and two novel Kudoa spp., K. trachuri n. sp. and K. thunni n. sp. (Myxosporea: Multivalvulida), from daily consumed marine fish in western Japan. Parasitol. Res. 108: 913-926.

Miller T.L., Adlard R.D. 2012: Brain infecting kudoids of Australia's coral reefs, including a description of Kudoa lemniscati n. sp. (Myxosporea: Kudoidae) from Lutjanus lemniscatus (Perciformes: Lutjanidae) off Ningaloo Reef, Western Australia. Parasitol. Int. 61: 333-342.

Moran J.W.D., Kent M. 1999: Review of the myxosporean genus Kudoa Meglitsch, 1947, and its impact on the international aquaculture industry and commercial fisheries. Aquaculture 172: 163-196.

SChärer L., Vizoso D. 2003: Earlier sex change in infected individuals of the protogynous reef fish Thalassoma bifasciatum. Behav. Ecol. Sociobiol. 55: 137-143.

Shirakashi S., Morita A., Ishimaru K., Miyashita S. 2012: Infection dynamics of Kudoa yasunagai (Myxozoa: Multivalvulida) infecting brain of cultured yellowtail Seriola quinqueradiata in Japan. Dis. Aquat Org. 101: 123-130.
Swearer S.E., Robertson D.R. 1999: Life history, pathology, and description of Kudoa ovivora n. sp. (Myxozoa, Myxosporea): an ovarian parasite of Caribbean labroid fishes. J. Parasitol. 85: 337-353.

Tamura K., Peterson D., Peterson N., Stecher G., Nei M., Kumar S. 2011. MEGA5: molecular evolutionary genetics analysis using maximum likelihood, evolutionary distance, and maximum parsimony methods. Mol. Biol. Evol. 28: 2731-2739.

Whipps C.M., Adlard R.D., Bryant M.S., Lester R.J., FindLAY V., Kent M.L. 2003: First report of three Kudoa species from eastern Australia: Kudoa thyrsites from mahi mahi (Coryphaena hippurus), Kudoa amamiensis and Kudoa minithyrsites n. sp. from sweeper (Pempheris ypsilychnus). J. Euk. Microbiol. 50: $215-219$.

Whipps C.M., Grossel G., Adlard R.D., Yokoyama H., Bryant M.S., Munday B.L., Kent M.L. 2004: Phylogeny of the Multivalvulidae (Myxozoa: Myxosporea) based on comparative ribosomal DNA sequence analysis. J. Parasitol. 90: 618-622.

Zhang J.Y., Meng F., Yokoyama H., Miyahara J., Takami I., OGAWA K. 2010: Myxosporean and microsporidian infections in cultured Pacific bluefin tuna Thunnus orientalis in Japan. Fish Sci. 76: $981-990$.

Cite this article as: Mansour L., Harrath A.H., Abdel-Baki A.-A.S., Alwasel S., Al-Quraishy S., Al Omar S.Y. 2015: Kudoa saudiensis sp. n. (Myxosporea: Multivalvulida) infecting oocytes of the Indian mackerel Rastrelliger kanagurta (Perciformes: Scombridae). Folia Parasitol. 62: 010. 